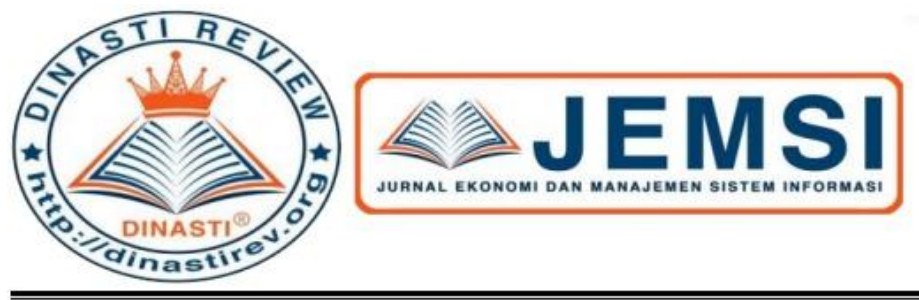

+62 878-9658-6407

087896586407 ()

https://dinastirev.org/JEMS I (6)

editor@dinastirev.org (.)

\title{
PERANAN BRAINWARE DALAM SISTEM INFORMASI MANAJEMEN
}

\section{Alfriza Frisdayanti}

Universitas Mercu Buana,Jakarta

\begin{tabular}{|c|c|}
\hline $\begin{array}{c}\text { ARTICLE INFORMATION } \\
\text { Received: Agustus } 2019 \\
\text { Revised: 31 Agustus } 2019 \\
\text { Issued: } 5 \text { September } 2019 \\
\text { Corresponding author: first author } \\
\text { E-mail: } \\
\text { my.manuscript01@gmail.com }\end{array}$ & $\begin{array}{l}\text { Abstrak: Sistem informasi manajemen sangat } \\
\text { bergantung dari komponen-komponen dalam } \\
\text { menghasilkan sistem informasi yang sesuai dengan } \\
\text { kebutuhannya. Kesenjangan yang terjadi dalam } \\
\text { pelaksanaan komponen tersebut akan menghasilkan } \\
\text { informasi yang kurang akurat, kurang detail, kurang } \\
\text { tepat waktunya dan kurang relevan akan } \\
\text { mengakibatkan kesalahan dalam pengambilan } \\
\text { keputusan pada perusahaan atau organisasi. Oleh } \\
\text { sebab itu perlu adanya pemahaman yang mendalam } \\
\text { mengenai komponen-komponen dalam sistem } \\
\text { informasi manajemen khususnya brainware agar dapat } \\
\text { menghasilkan informasi yang bernilai guna bagi } \\
\text { perusahaan atau organisasi agar dapat memperoleh } \\
\text { sustainable competitive advantages. Sistem informasi } \\
\text { manajemen tergantung pada komponen dalam } \\
\text { menghasilkan sistem informasi yang sesuai dengan } \\
\text { kebutuhan mereka. Kesenjangan dalam pelaksanaan } \\
\text { komponen ini akan menghasilkan informasi yang } \\
\text { kurang akurat, kurang rinci, kurang tepat dan kurang } \\
\text { relevan waktu akan mengakibatkan kesalahan dalam } \\
\text { pengambilan keputusan di perusahaan atau organisasi. } \\
\text { Oleh karena itu kebutuhan untuk pemahaman yang } \\
\text { mendalam dari komponen dalam pengelolaan sistem } \\
\text { informasi dalam bergerak tertentu diharapkan untuk } \\
\text { menghasilkan informasi yang berharga agar } \\
\text { perusahaan atau organisasi untuk mendapatkan } \\
\text { keuntungan kompetitif yang berkelanjutan. Sesuai } \\
\text { dengan zaman hari ini bahwa dalam pengelolaan } \\
\text { sumber daya manusia secara efektif, setiap organisasi } \\
\text { mutlak diperlukan untuk menciptakan sumber daya } \\
\text { manusia sistem informasi untuk pengembangan sistem } \\
\text { informasi dapat mempengaruhi pengambilan } \\
\text { keputusan dalam Lembaga. Diharapkan dimainkannya } \\
\text { adalah proses ke arah yang lebih baik sehingga dengan } \\
\text { pegetahuan perolehan dari sistem informasi akan } \\
\text { menambah wacana, pertimbangan dan akhirnya }\end{array}$ \\
\hline
\end{tabular}


memutuskan dengan tepat. Untuk sistem informasi terdiri dari komponen yang mendukung lembaga pendidikan untuk memberikan informasi yang dibutuhkan oleh pengambil keputusan ketika melakukan kegiatan pendidikan.

Kata Kunci: brainware, informasi, sistem informasi, sistem informasi manajemen.

\section{PENDAHULUAN}

Persaingan dalam dunia usaha yang semakin kompetitif mengakibatkan perusahaan melakukan strategi usaha yang tepat agar dapat memenangkan atau bertahan dalam menghadapinya. Dalam organisasi modern agar perusahaan dapat bertahan dalam persaingan usaha perlu memperhatikan market driven dan coustomer driven sehingga sustainable competitive advantage dapat diperoleh. Perusahaan tersebut harus memperhatikan focus pada unsur kinerjanya dengan memperhatikan customer satisfaction. Peran sistem informasi manajemen memainkan peran strategis dalam menghadapi persaingan bebas pada saat ini. Dimana sistem informasi dan teknologi informasi yang dipadukan dengan komponen lain seperti proses, prosedur, struktur organisasi, sumber daya manusia, manajemen, budaya organisasi dan komponen terkait lainnya dalam membentuk sistem informasi manajemen yang baik merupakan salah satu kunci keberhasilan dari perusahaan.

Sistem informasi merupakan sebagai satuan komponen yang saling berhubungan yang mengumpulkan (atau mendapatkan kembali), memproses, menyimpan, dan mendistribusikan informasi untuk mendukung pengambilan keputusan dan kendali dalam suatu organsasi. Selain itu sistem informasi juga membantu para manajer untuk meneliti permasalahan, memvisualisasikan pokok-pokok yang kompleks dan menciptakan produkproduk baru. Dapat dikatakan sistem informasi adalah serangkaian prosedur formal di mana data dikumpulkan. Sistem informasi adalah paduan dari berbagai resources baik hardware, software, netware, brainware, dan data. Dalam sistem informasi juga ada input, model, proses, output, penyimpanan dan kontrol, sehingga sistem informasi dapat digunakan untuk merencanakan, mengolah, mengendalikan serta meracik data dalam suatu organisasi berdasarkan critical sukses untuk menentukan keberhasilan perusahaan.

Secara umum, sistem terdiri dari elemen-elemen yang saling berhubungan membentuk satu kesatuan untuk melaksanakan suatu tujuan pokok dari sistem tersebut. Tujuan pokok dari sistem komputer adalah mengolah data untuk menghasilkan informasi sehingga perlu didukung oleh elemen- elemen yang terdiri dari perangkat keras (hardware), perangkat lunak (software) dan pengguna (brainware). Perangkat keras adalah peralatan komputer itu sendiri, perangkat lunak adalah program yang berisi perintah-perintah untuk melakukan proses tertentu, dan brainware adalah manusia yang terlibat di dalam mengoperasikan serta mengatur sistem komputer.

Ketiga elemen sistem komputer tersebut harus saling berhubungan dan membentuk satu kesatuan. Perangkat keras tanpa perangkat lunak tidak akan berarti apa-apa, hanya berupa benda mati. Kedua perangkat keras dan lunak juga tidak dapat berfungsi jika tidak ada manusia yang mengoperasikannya. Data sebagai sebuah sumber daya dalam suatu organisasi atau perusahaan perlu dikelola dengan baik, manajemen sumber daya data yang berbasis komputer menekankan pentingnya manajemen database dan aplikasinya dalam sistem informasi manajemen. 
Proses data terdistribusi merupakan suatu konsep penyebaran komputer dan peralatan, perangkat lunak dan data yang dihubungkan dengan alat komunikasi dengan perangkat yang ada pada lokasi lain. Proses data terdistribusi sudah menjadi keharusan dengan kemajuan sistem komunikasi pada saat ini khususnya oleh komponen brainware. Tulisan ini meninjau peranan brainware dalam sistem informasi manajemen. Tulisan ini dimulai dengan melakukan reviu tentang konsep teori atau kajian teori untuk memberikan gambaran mengenai brainware dan sistem informasi manajemen, kemudian dilanjutkan dengan ulasan mengenai peranan brainware dalam sistem informasi manajemen dan diakhiri dengan mengajukan suatu proposisi

\section{KAJIAN PUSTAKA \\ Pengertian Sistem}

Sistem menurut para ahli, pengertian sistem dapat diartikan sebagai berikut; menurut Ludwig von Bartalanfy, sistem merupakan seperangkat unsur yang saling terikat dalam suatu antar relasi diantara unsur-unsur tersebut dengan lingkungan. Sedangkan menurut Anatol Raporot, sistem adalah suatu kumpulan kesatuan dan perangkat hubungan satu sama lain dan Menurut L. Ackof, Sistem adalah setiap kesatuan secara konseptual atau fisik yang terdiri dari bagian-bagian dalam keadaan saling tergantung satu sama lainnya. (Susanto, 2004).

Menurut Romney (2004), pengertian sistem merupakan suatu rangkaian dari dua atau lebih komponen-komponen yang saling berhubungan, yang berinteraksi untuk mencapai suatu tujuan. Sedangkan menurut Hall (2007) sistem adalah kelompok dari dua atau lebih komponen atau subsistem yang saling berhubungan yang berfungsi dengan tujuan yang sama. Adapun pengertian sistem dan menghasilkan informasi sebagaimana yang dikemukakan oleh The American National Standards Committee dalam La Midjan dan Susanto (2004) adalah sistem dalam pengolahan data, suatu kumpulan dari manusia, mesin dan metode yang terorganisir untuk memenuhi seperangkat fungsi.

Sistem terdiri dari tiga unsur yaitu: input (masukan), proses dan output (pengeluaran). Input merupakan komponen penggerak atau pemberi tenaga di mana sistem itu dioperasikan, sedangkan output adalah hasil operasi. Dalam pengertian sederhana output berarti yang menjadi tujuan sasaran atau target pengoperasian suatu sistem sedangkan proses merupakan aktivitas yang dapat mentransformasikan input menjadi output.

Berikut ini dikemukakan sifat dari sistem sebagaimana merujuk kepada La Midjan dan Susanto (2004) yaitu:

1) Tujuan Sistem, merupakan target atau sasaran akhir yang ingin dicapai oleh suatu sistem,

2) Batas Sistem, merupakan garis abstraksi yang memisahkan antara sistem dan lingkungannya,

3) Subsistem, merupakan komponen atau bagian dari suatu sistem, subsistem ini bisa phisik ataupun abstrak,

4) Hubungan dan Hirarki Sistem, merupakan hubungan yang terjadi antar subsistem dengan subsistem lainnya yang setingkat atau antara subsistem dengan sistem yang lebih besar,

5) Input-Proses-Output, yaitu sebagai masukan, diolah untuk menghasilkan berbagai keluaran, dan

6) Lingkungan Sistem, merupakan factor-faktor di luar sistem yang mempengaruhi sistem.

Dari beberapa definisi sistem di atas, maka dapat disimpulkan, sistem adalah sekumpulan unsur / elemen yang saling berkaitan dan saling mempengaruhi dalam melakukan kegiatan bersama untuk mencapai suatu tujuan. Sebagai contoh, dalam sistem komputer terdapat software, hardware, dan brainware. 


\section{Pengertian Informasi}

Pengertian dari informasi menurut Kusrini dan Koniyo (2007) adalah data yang sudah diolah menjadi sebuah bentuk yang berarti bagi pengguna, yang bermanfaat dalam pengambilan keputusan saat ini atau mendukung sumber informasi. Sedangkan informasi menurut Susanto (2004) merupakan hasil dari pengolahan data yang memberikan arti dan manfaat. Dari pengertian di atas, dapat dikesimpulan bahwa data harus diolah terlebih dahulu agar dapat menjadi informasi yang berguna untuk pemakai informasi. Yang bersumber dari suatu pengolahan data harus merupakan suatu informasi yang memenuhi kriteria tepat waktu, relevan dan handal.

Dari uraian tentang informasi, ada tiga hal penting yang harus diperhatikan menurut Susanto (2004) yaitu sebagai berikut: (1) Informasi merupakan hasil pengolahan data, (2) Memberikan makna atau arti, dan (3) Berguna atau bermanfaat. Lebih jauh Mc. Leod (Susanto, 2008) menyatakan bahwa suatu informasi yang berkualitas harus memiliki ciri-ciri sebagai berikut: (1) Akurat, artinya informasi harus mencerminkan keadaan yang sebenarnya, (2) Tepat Waktu, artinya informasi itu harus tersedia atau ada pada saat informasi tersebut diperlukan, tidak besok atau tidak beberapa jam lagi, (3) Relevan, artinya informasi yang diberikan harus sesuai dengan yang dibutuhkan oleh individu yang ada di berbagai tingkatan dan bagian dalam organisasi, dan (4) Lengkap, maksudnya informasi harus diberikan secara lengkap.

Dan menurut Gelinas (Susanto, 2004) ciri-ciri informasi yang lain yang lebih detail dibandingkan dengan apa yang diusulkan oleh Mc. Leod, ciri-ciri tersebut adalah: (1) Efektifitas, artinya informasi harus sesuai dan secara lengkap mendukung kebutuhan pemakai dalam mendukung proses bisnis dan tugas pengguna serta disajikan dalam waktu dan format yang tepat, konsisten dengan format sebelumnya sehingga mudah dimengerti, (2) Efisiensi, artinya informasi yang dihasilkan melalui penggunaan sumber daya yang optimal,(3) Confidensial, artinya informasi sensitif terlindungi dari pihak yang tidak berwenang, (4) Integritas, artinya informasi yang dihasilkan harus merupakan hasil pengolahan data yang terpadu dan aturan yang berlaku, (5) Ketersediaan, artinya informasi yang diperlukan harus selalu tersedia kapanpun saat diperlukan. Untuk itu diperlukan pengamanan terhadap sumber daya informasi, (6) Kepatuhan, artinya informasi yang dihasilkan harus patuh terhadap undang-undang atau peraturan pemerintah serta memiliki tanggung jawab baik terhadap pihak internal maupun pihak eksternal organisasi perusahaan, dan (7) Kebenaran informasi, artinya informasi telah disajikan oleh sistem informasi dengan benar dan dapat dipercaya sehingga dapat digunakan oleh manajemen untuk mengoperasikan perusahaan.

Sedangkan menurut Widjajanto (2001) kualitas informasi yang baik itu yaitu;(1) Kecermatan (accuracy), yaitu perbandingan antara informasi yang benar terhadap total informasi yang dihasilkan dalam suatu periode, (2) Penyajian yang Tepat Waktu (Timeliness), yaitu kegiatan menyajikan informasi pada saat transaksi terjadi atau pada saat informasi tersebut dibutuhkan, yang mampu menutup peluang bagi pesaing untuk mengambil keputusan yang baik dengan lebih cepat, (3) Kelengkapan (completeness), yaitu Adanya relevansi antara informasi dan penggunanya, dan (4) Ringkas (conciseness), yaitu informasi yang disajikan telah diikhtisarkan sesuai kebutuhan pengguna dan bidang-bidang yang menjadi fokus utama.

\section{Pengertian Sistem Informasi}

Pengertian sistem informasi menurut Laudon (La Midjan dan Susanto, 2004) adalah komponen- komponen yang saling berhubungan dan bekerja sama untuk mengumpulkan,memproses, menyimpan dan menyebarkan informasi untuk mendukung pengambilan keputusan, koordinasi, pengendalian dan untuk memberikan gambaran aktivitas 
di dalam perusahaan. Sedangkan sistem informasi menurut Hall (2004) merupakan serangkaian prosedur formal di mana data dikumpulkan, diproses menjadi informasi dan didistribusikan ke para pengguna.

Adapun Laitch dan Bavis (Kusrini dan Koniyo, 2007) sistem informasi merupakan suatu sistem di dalam suatu organisasi yang mempertemukan kebutuhan pengolahan transaksi harian, mendukung operasi, bersifat manajerial dan kegiatan strategi dari suatu organisasi dan menyediakan pihak luar tertentu dengan laporan-laporan yang diperlukan. Lebih lanjut menurut Cushing (La Midjan dan Susanto, 2004), informasi yang dihasilkan berasal dari pengolahan data yang terstruktur yaitu data yang memenuhi fungsi (a) Keabsahan formal yaitu telah melalui prosedur pembuatan dan pengumpulan data yang benar artinya jelas otorisasinya dan secara yuridis sah, dan Keabsahan material dalam arti data tersebut telah mewakili suatu transaksi keuangan yang terjadi dan benar pula. Sedangkan menurut La Midjan dan Susanto (2004), sumber dari sistem informasi di dalam perusahaan yang bersumber dari alat-alat pemroses/pengolah data adalah:

1) Otak, otak manusia memiliki dua macam memori yaitu memori jangka panjang dan memori jangka pendek,

2) Manual, alat pengolah manual ditandai dengan penggunaan pena dan tinta,

3) Mekanik, mekanik memberikan hasil pengolahan yang lebih cepat, lebih rapih dan sama/standar,

4) Elektrik, dan

5) Elektronik, elektronik memberikan kecepatan dan efisiensi pengolahan.

\section{Pengertian Sistem Informasi Manajemen}

Sistem informasi manajemen merupakan bagian dari pengendalian internal suatu bisnis yang meliputi pemanfaatan sumber daya manusia, dokumen, teknologi, dan prosedur oleh manajemen untuk memecahkan masalah bisnis. Sistem informasi manajemen, istilah yang umum dikenal orang adalah sebuah sistem manusia/mesin yang terpadu (intregeted) untuk menyajikan informasi guna mendukung fungsi operasi, manajemen, dan pengambilan keputusan dalam sebuah organisasi. Sistem ini menggunakan perangkat keras (hardware) dan perangkat lunak (software) komputer, prosedur pedoman, model manajemen dan keputusan, dan sebuah "data base".

Susanto (2004) menyatakan bahwa sistem informasi manajemen merupakan kumpulan dari sub-sub sistem yang salaing berhubungan satu sama lain dan bekerja sama secara harmonis untuk mencapai tujuan yaitu mengolah data menjadi informasi yang dipelukan oleh manajemen dalam proses pengambilan keputusan saat melaksanakan fungsinya.

Sistem informasi manajemen dapat dibedakan dengan sistem informasi biasa karena digunakan untuk menganalisis sistem informasi lain yang diterapkan pada aktivitas operasional organisasi. Secara akademis, istilah ini umumnya digunakan untuk merujuk pada kelompok metode manajemen informasi yang bertalian dengan otomasi atau dukungan terhadap pengambilan keputusan, misalnya sistem pendukung keputusansistem pakar, dan sistem informasi eksekutif.

Dari uraian diatas dapat disimpulkan, sistem informasi manajemen adalah suatu sistem yang dirancang untuk menyediakan informasi guna mendukung pengambilan keputusan pada kegiatan manajemen (perencanaan, penggerakan, pengorganisasian, dan pengendalian) dalam organisasi. 


\section{Komponen Sistem Informasi Manajemen}

Menurut Susanto (2004) komponen dalam sebuah informasi akuntansi yang terintegrasi dalam sebuah sistem yang bekerja secara harmonis dalam rangka menghasilkan informasi yang dapat diandalkan oleh para pemakai. Dalam konsep sistem informasi manajemen yang harus diintegrasikan adalah semua unsur dan subunsur yang terkait dalam membentuk suatu sistem informasi manajemen yang berkualitas. Unsur- unsur tersebut juga disebut sebagai komponen sistem informasi akuntansi yang terdiri dari hardware, software, brainware, prosedur, database dan jaringan komunikasi.

Adapun komponen sistem informasi manajemen menurut Susanto (2004) yaitu;

1) Hardware (perangkat keras), peralatan phisik yang dapat digunakan untuk mengumpulkan, memasukkan, memproses, menyimpan, dan mengeluarkan hasil pengolahan data dalam bentuk informasi,

2) Software (perangkat lunak), kumpulan dari program-program yang digunakanuntuk menjalankan komputer atau aplikasi tertentu pada computer,

3) Brainware, sumber daya manusia yaitu bagian terpenting dari komponen sistem informasi manajemen,

4) Prosedur yaitu rangkaian aktivitas atau kegiatan yang dilakukan secara berulang-ulang dengan cara yang sama,

5) Basis data yaitu suatu pengorganisasian sekumpulan data yang saling terkait sehingga memudahkan proses pencarian informasi, dan

6) Jaringan komputer dan komunikasi data.

\section{Brainware}

Brainware merupakan orang yang memiliki, membangun dan menjalankan sistem informasi manajemen. Istilah orang disini bukan sembarang orang dalam arti wujudnya orang akan tetapi orang yang memiliki kompetensi (ilmu pengetahuan dan keterampilan atau keahlian). Misalnya, Programer yaitu membuat atau menyempurnakan program komputer yang digunakan saat ini. Programer harus memiliki kompetensi (ilmu pengetahuan dan keterampilan atau keahlian) dan sesuai dengan jenjangnya mengenai sistem informasi, memiliki pendidikan minimal D3 ilmu komputer dan informasi, atau berpengalaman di bidang komputer akuntansi. Brainware dikelompokan sebagai berikut:

a) Manajer system informasi (manajemen/akuntansi),

b) Analis sistem,

c) Ahli komunikasi,

d) Administrator database,

e) Programer,

f) Operator, dan

Pustakawan. Integrasi komponen brainware mengandung arti semua kelompok brainware tersebut harus dapat bekerja sama secara harmonis dalam mendukung beroperasinya sistem informasi manajemen. Brainware (User) merupakan personil-personil yang terlibat langsung dalam pemakaian komputer, seperti sistem analis, programmer, operator, user, dll. Pada organisasi yang cukup besar, masalah komputerisasi biasanya ditangani oleh bagian khusus yang dikenal dengan bagian EDP (Electronic Data Processing), atau sering disebut dengan EDP Departemen, yang dikepalai oleh seorang Manager EDP.

Sistem mengandung arti unsur keterkaitan antar komponen-komponen, sedangkan system informasi mengandung arti kumpulan komponen - komponen dalam perusahaan atau organisasi dalam rangka menghasilkan proses penciptaan dan pengaliran informasi. Sehingga 
dalam sistem informasi manajemen dibutuhkan keseimbangan antar komponen- komponen dalam menghasilkan suatu sistem informasi sesuai dengan kebutuhannya. Sistem informasi manajemen ini juga dapat dianalogikan sebagai unsur permintaan dan penawaran seperti dalam ilmu ekonomi. Sisi permintaan merupakan permintaan akan sarana pengolahan data informasi secara cepat, akurat, detail dan relevan, sementara di sisi penawaran berupa produk-produk teknologi informasi dalam memenuhi kebutuhan akan informasi seperti software dan hardware.

Keseimbangan dalam sisi permintaan dan penawaran sangat penting bagi perusahaan atau organisasi. Dimana kebutuhan perusahaan atau organisasi akan teknologi informasi sangat beragam tergantung dari jenis dan karakteristik dari perusahaan atau organisasi masing-masing. Suatu sistem informasi yang baik belum tentu harus dimiliki dengan produkproduk teknologi yang canggih, misalnya perusahaan pengrajin dengan omset milyaran rupiah, akan tetapi berbeda dengan perusahaan manufaktur seperti perakitan mobil yang membutuhkan perangkat produk-produk teknologi canggih dalam memproses produksinya

\section{METODE PENELITIAN}

Perkembangan informasi khususnya internet menimbulkan suatu keseimbangan antara brainware, hardware dan software. Pada saat ini internet yang merupakan hasil dari teknologi informasi memegang peranan penting bagi perusahaan khususnya perusahaan yang berorientasi pada pengembangan inovasi. Brabham, (2008) dan Corrocher, (2011) menyatakan perkembangan internet mengkibatkan terbentuknya suatu open innovation webbased platforms (OIPs), yaitu kolaborasi antara perusahaan- perusahaan dengan individuindividu sebagai pengembang suatu sisstem operasi serta perangkat produk teknologi informasi. Inovasi merupakan suatu keniscayaan yang harus dikembangkan oleh perusahaan untuk meningkatkan daya saingnya dalam dunia usaha. Pada saat ini perusahaan mengetahui tentang potensi komunitas dari pelanggan, karyawan, rekan bisnis dan stakeholders sebagai sumber dari informasi yang bernilai guna bagi keputusan manajemen (Battistella dan Nonino, 2012). Peran komunitas terhadap perusahaan sebagai sumber informasi merupakan asset yang berharga dalam menghasilkan informasi yang akurat dan bernilai bagi perusahaan (Mourillo, 2011). Dengan mengoptimalkan open innovation web- based platforms (OIPs) maka manajemen dapat memperoleh informasi yang akurat dan relevan dalam memenuhi kebutuhan dan keinginan dari pelanggannya (Nakki dan Antikainen, 2008).

Lebih lanjut hasil pengolahan informasi yang bernilai guna bagi perusahaan atau organisasi sangat ditentukan oleh identifikasi atas sisi kebutuhan akan informasi yang akurat, detail, tepat waktu dan relevan serta atas sisi penggunaan produk-produk teknologi informasi. Becker (2002) yang melakukan penelitian terhadap perusahaan di Negara Eropa mengenai bagaimana perusahaan dalam mengidentifikasi perubahan pasar dan konsumen serta kesiapan perusahaan dalam menghadapi ketidak pastian pada masa depan dan cara agar tetap bertahan pada persaingan yang sangat ketat, dalam kaitannya dengan pengolaan sistem informasi manajemen, perusahaan perlu untuk memanfaatkan komponen-komponen yang ada agar dapat menghasilkan informasi yang bernilai guna bagi perusahaan. Dengan demikian perlu adanya identifikasi terhadap kebutuhan user dalam perusahaan. Hal ini diungkapkan oleh Indrajit (2007) yang menyatakan bahwa perlu adanya identifikasi terhadap user agar proses sistem manajemen dapat berjalan dengan baik. 
Demikia pula Susanto (2004) yang menyatakan bahwa user perlu diperhatikan lebih dalam karena menyangkut penentuan masalah yang harus dipecahkan, kesempatan yang harus diambil, kebutuhan-kebutuhan yang harus dipenuhi dan batasan-batasan bisnis yang harus termuat dalam sistem informasi manajemen. Leung (1996) menyatakan terdapat tujuh aspek penting dalam mengidentifikasikan kebutuhan user yaitu;

1) understanding the business,

2) find out what the users want,

3) beware what the users tell you,

4) select appropriate interview schedule,

5) don't bring I/T into conversation,

6) don't forget the operational site, dan

7) get ready to document everything.

\section{HASIL DAN PEMBAHASAN}

Mengetahui kebutuhan users dalam perusahaan akan meningkatkan keberhasilan dalam melaksanakan sistem informasi manajemen untuk menghasilakan informasi yang bernilai guna tinggi dalam rangka pengambilan keputusan. Peranan brainware dalam sistem informasi manajemen dapat dilihat dari penggunaan asset tenologi informasi. Ross et al., dalam Indrajit (2007) menyatakan bahwa hasil risetnya terhadap perusahaan di Amerika terdapat 3 aset penting agar perusahaan dapat memenangkan persaingan dalam persaingan usaha yaitu sumber daya manusia, teknologi dan relasi yang biasa di sebut dengan The three information technology assets.

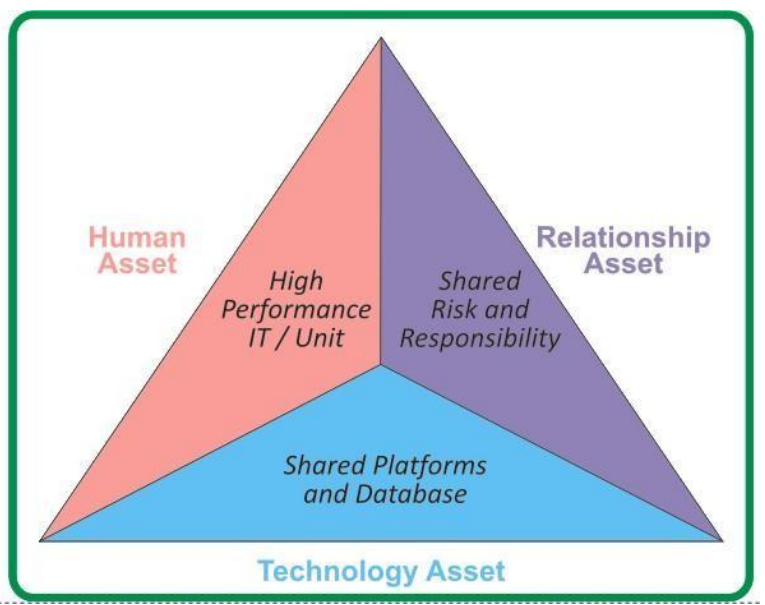

Gambar 1. The asset of information technology

Dari gambar diatas dapat dilihat terdapat Aset Sumber daya manusia, berupa para staff penanggung jawab dan pengembangan teknologi diperusahaan. Aset Teknologi, merupakan seluruh infrastruktur teknologi informasi yang meliputi hardware dan software. Aset relasi, yaitu hubungan teknologi informasi dengan para pemegang manajemen dalam melakukan pengambilan keputusan.

Lebih lanjut Indrajit (2007) menyatakan dalam aset sumber daya manusia perlu untuk memperhatikan keahlian teknis, pengetahuan bisnis dan orientasi pada pemecahaan masalah karena kebutuhan akan sumber daya manusia yang memiliki kemampuan teknis merupakan critical factor dalam perusahaan atas pesatnya kemajuan teknologi informasi. Aset teknologi 
merupakan tulang punggung bagi perusahaan agar tercipta integrasi sistem informasi dengan biaya seefektif mungkin baik untuk pengembangan, operasional maupun pemeliharaan. Dalam hal aset relasi berhubungan dengan membagi resiko dan tanggung jawab dalam kaitannya dengan membangun hubungan dengan teknologi informasi. Senada dengan itu Romero dan Molina (2011) menemukan bahwa kolaborasi network perusahaan dengn pelanggan sangat berpengaruh terhadap penciptaan nilai perusahaan dalam meningkatkan innovasi khususnya terhadap produk teknologi informasi serta metode dalam melakukan identifikasi terhadap ekosistem lingkungan bisnis sangat berpengaruh erat dalam menghasilkan informasi yang bernilai guna bagi perusahaan.

\section{KESIMPULAN DAN SARAN}

\section{Kesimpulan}

Dengan demikian dapat dipahami bahwa komponen brainware ini merupakan bagian yang tidak terpisahkan dari komponen lainnya dalam suatu sistem informasi manajemen sebagai hasil dari perencanaan, analisis, perancangan, dan strategi implementasi yang didasarkan pada transformasi informasi diantara sumber daya manusia yang terlibat dalam perusahaan. Keterlibataan ini berkaitan dengan pemantau, pengoperasian, dan penggunaan sistem informasi yang memberikan dampak pada manajemen serta ikut dalam menentukan tingkat kesuksesan perusahaan untuk memperoleh sustainable competitive advantages. Berdasarkan pada pembahasan diatas maka penulis mengajukan proposisi sebagai berikut; Brainware berpengaruh signifikan terhadap pelaksanaan sistem manajemen informasi dalam rangka menghasilkan informasi yang akurat, detail, tepat waktu dan relevan sesuai dengan tujuan perusahaan untuk memperoleh sustainable competitive advantages.

\section{Saran}

Brainware merupakan salah satu dari komponen dalam sistem informasi manajemen. Keberhasilan sistem informasi manajemen dalam menghasilkan informasi yang akurat, detail, tepat waktu dan relevan sangat bergantung dari komponen-komponen tersebut. Analisis gap terhadap sistem infomasi manajemen yang dilakukan oleh perusahaan atau organisasi dapat informasi manajemen dapat tercapai dengan maksimal dan bernilai guna meminimalisir kesenjangan tersebut. Sehingga tujuan perusahaan atau organisasi dalam pelaksanaan sistem tinggi. Dengan demikian peranan brainware yang merupakan salah satu komponen sistem informasi manajemen sangat penting untuk diperhatikan dan diperlakukan sama pentingnya dengan komponen yang lainnya dalam menghasilkan informasi yang berguna bagi manajemen dalam proses pengambilan keputusan.

\section{DAFTAR RUJUKAN}

Battistella, C., Nonino, F,. (2012). Open innovation web-based platforms: The impact of different forms of motivation on collaboration. Innovation: Management, Policy \& Practice. 14(4), 557-575.

Brabham, D, C., (2008). Crowdsourcing as a model for problem solving: An introduction and cases. Convergen: The International Journal of Research into New Media Technologies. 14(1), 75-90.

Becker, P., (2002). Corporate foresight in Europe: A first overviews. Institute for Science and Technology Studies. Retrieved form ftp://ftp.cordis.europa.eu/pub/f oresight/docs/st_corporate_for esight_040109.pdf

Corrocher, N., (2011). The adoption of Web 2.0 services: An empirical investigation. Technological Forecasting and Social Change. 78(4), 547-558. 
Hall, J, A., (2004). Sistem Informasi Akuntansi. Jakarta: Penerbit Salemba Empat.

Indrajit, R, E., (2007). Manajemen Sistem Informasi dan Teknologi Informasi.Pengantar Konsep Dasar. Jakarta: STIMIK PERBANAS. Renaissance Center.

Kusrini,. Koniyo, A,. (2007). Tuntunan Praktis Membangun Sistem Informasi Akutansi Dengan Visual Basic dan Microsoft SQL Server. Yogyakarta: Penerbit Andi.

La Midjan dan Susanto, A,. (2008). Sistem Informasi Akuntansi Konsep dan Pengembangannya. Bandung: Penerbit Lingga Jaya.

Leung, L., (1996). Computing.September 12 Edition.

Romero, D,. Molina, A., (2011). Collaborative networked organizations and custome communities: Value co- creation and co-innovation in the networking era. Production Planning and Control. 22(5- 6),477-472.

Widjadjanto, N,. (2001). Sistem Informasi Akuntansi. Jakarta: Penerbit Erlangga. Romney, M., Steinbart, P, J., (2005). Accounting Information Systems 9th Edition. Jakarta: Penerbit Salemba Empat.

Susanto, A,. (2004). Sistem Informasi Manajemen Konsep dan Pengembangannya. Bandung: Penerbit Lingga Jaya. 